九州大学学術情報リポジトリ

Kyushu University Institutional Repository

\title{
Comparison of Yield in Korean Small Seed Soybean Cultivars with Main Stem and Branch Production
}

Cho, Jin-Woong

Honam Agricultural Research Institute, National Institute of Crop Science, Korea

Park, Gwan-Soo

Chungnam National University

Yamakawa, Takeo

Department of Plant Resources, Kyushu University

Ohga, Shoj i

Department of Forest and Forest Prducts Sciences, Kyushu University

https://doi.org/10.5109/4665

出版情報: 九州大学大学院農学研究院紀要. 50 (2)，pp.511-519，2005-10-01. Faculty of Agriculture, Kyushu University

バージョン：

権利関係 : 


\title{
Comparison of Yield in Korean Small Seed Soybean Cultivars with Main Stem and Branch Production
}

\author{
Jin-Woong CHO', Gwan-Soo PARK ${ }^{2}$, Takeo YAMAKAWA \\ and Shoji OHGA*
}

\author{
Laboratory of Forest Resources, Division of Forest Ecosphere \\ Sciences and Management, Department of Forest and Forest Products Sciences, \\ Kyushu University, Fukuoka 811-2415, Japan \\ (Received June 16, 2005 and accepted July 26, 2005)
}

\begin{abstract}
This study was carried out to investigate the agronomic characteristics of late-planted small seed soybean cultivars and to investigate the effect of number of pods and seeds on main stem and branch against seed yield in Korea. Seed were sown at 17 June 2003 and 16 June 2004 with on a $60 \mathrm{~cm}$ row width and $10 \mathrm{~cm}$ plant space. The flowering dates in small seed soybean cultivars were on July 26 to August 7 and the maturing dates were on September 23 to October 9. The days of from planting to flowering date and to maturing date were ranged as 39 $\sim 52$ and $98 \sim 114$, respectively. There was a highly significant difference $(r=0.686, p<0.01)$ between total dry matter (TDM) and LAI at R5 stage. The number of pods on $2^{\text {nd }}$ branch showed the highest value by 7.6 , and followed by that of $3^{\text {rd }}, 1^{\text {st }}$ and over $4^{\text {th }}$ branch in this order. The seed yield varied from 168 to $289 \mathrm{~g} \mathrm{~m}^{-2}$ and the average of all soybean cultivars was $225 \mathrm{~g}$ $\mathrm{m}^{-2}$. The relation between the seed yield and the days of flowering to maturing date was high significant difference $(\mathrm{r}=0.575, \mathrm{p}<0.01)$ and there was a high significance difference $(\mathrm{r}=$ $0.781, \mathrm{p}<0.01$ ) between the seed yield and the days of planting to flowering date. The level of significant difference was. higher in the period of vegetative stage than in the period of reproductive stage in small seed soybeans. There was high significance difference $(r=0.556$, $\mathrm{p}<0.01$ ) between the seed yield and LAI in soybean cultivars. A range of LAI for optimal seed yield may be shown about 3.5 4.5 at $R 5$ stage. Also, there was a relationship between the seed yield and the number of pods on $4^{\text {th }}$ and above branch but was no significant relationship between the seed yield and number of pods on $1^{\text {st }}$ branch. The correlation between the seed yield and the pods numbers showed the most value by $0.640(\mathrm{p}<0.01)$ on $3^{\text {rd }}$ branch, and followed $2^{\text {nd }}$ branch, and $4^{\text {th }}$ and above branch in this order. There was a high significant relationship $(r=0.648, p<0.01)$ between the seed yield and the number of pods on total branch among 22 small seed soybean cultivars. However, the relation between the seed yield and the number of pods on main stem showed no significant relationship $(r=0.089$, ns). These results indicated that in order to optimal seed yield of late planted (mid-June) small seed soybean, soybean cultivars forming more pods on the $2^{\text {nd }}$ and $3^{\text {rd }}$ branch should be bred.
\end{abstract}

\section{INTRODUCTION}

Soybean, which is high content of protein and fat, is used in various sources such as food; industrial material, and forage, and the production and consumption of soybean

${ }^{1}$ Honam Agricultural Research Institute, National Institute of Crop Science, RDA, 570-080, Korea

2 Department of Forest Resources, Chungnam National University, Daejeon 305-764, Korea

${ }^{3}$ Laboratory of Plant Nutrition, Division of Soil Science and Plant Production, Department of Plant Resources, Kyushu University

* Corresponding author (E-mail: ohgasfor@mbox.nc.kyushu-u.ac.jp) 
increases every year in worldwide. The yield potential of soybean varies from 3,500 to $6,000 \mathrm{~kg}$ per ha. In Japan and USA the yield potential is up to $7,000 \mathrm{~kg}$ per ha (Paroda, 1999). But, in Korea, because of low gain yield per unit area and insufficient propagation of mechanization technology, cultivation area of soybean decreased rapidly by 297,000 ha in 1970 to 87,350 ha in 2000 (Cho et al.; 2004; Park et al. 2001). In Korea, total 103 cultivars including 22 small seed cultivars for vegetative sprout were released since 1906 (Lee and Park, 2001).

Soybean has been cultured as late planting (after mid-June), which is a common limiting factor for soybean production in the southern Korea due to maintain a double cropping after a winter crops. This delay reduced seed yield and affected negatively most agronomic characteristics compared with full season soybean (Quattara \& Weaver, 1994). Also, delayed planting reduced the days to maturity and flowering date, and decreased the length of vegetative and reproductive periods of development (Board et al:, 1996; Parker et al., 1981). Yield reduction in late-planted determinate soybean has been attributed to reduced vegetative growth caused by insufficient premature before flowering as a result of a shorter photoperiod at later planting dates (Weaver, et al.1991). Pfeiffer \& Pilcher (1987) stated that if early flowering would allow a longer period of seed filling, and thus potentially higher yields, the delay of flowering date may shorten the length of the reproductive period below the level needed to sustain high yield. On the other hand, yield responses of determinate soybean to narrow row culture in the southwest Korea have been inconsistent to that at optimal planting dates and some studies have shown a positive yield response to narrow rows when soybean cultivars were sown to narrow row spaces after mid-June (Board et al. 1996; Quattara \& Weaver, 1994). Therefore, this study was carried out to investigate the agronomic characteristics of late-planted small seed soybean cultivars and to investigate the effect of number of pods and seeds on main stem and branch of Korean small seed soybean cultivars.

\section{MATERIALS AND METHODS}

The research was carried out during 2003 and 2004 at farm affiliated to Honam Agricultural Research Institute in Iksan area, southwest part of Korea. This soil was characterized by a commercial silty clay loam texture. Twenty-two small seed soybean cultivars were used in this experiment. Seeds were sown on 17 June 2003 and 16 June 2004 at $60 \mathrm{~cm}$ of row width and $10 \mathrm{~cm}$ of plant space. The cultivated area of experimental plots was about $9.6 \mathrm{~m}^{2}$ per cultivar. This study was conducted randomized block design with three replications. The amount of applied fertilizer was $\mathrm{N} ; 3 \mathrm{~g}, \mathrm{P}_{2} \mathrm{O}_{5} ; 3 \mathrm{~g}$, and $\mathrm{K}_{2} \mathrm{O}$; $3.4 \mathrm{~g}$ per $\mathrm{m}^{2}$ with all basal fertilizations both for two years.

Three weeks after planting (about V3 stage), seedlings were thinned to two plants stand. Weeds were controlled by the incorporation of trifluralin (trifluoro-2, 6-dinitro- $N$, $N$-dipropyl- $p$-toluidine) before sowing and weeded by hand if necessary. Defoliating insects were controlled with insecticides as needed, and overhead sprinklers irrigated plots when needed. Duration of vegetative growth (days up to flowering stage) and reproductive growth $(\mathrm{R} 1 \sim \mathrm{R} 8)$ was recorded by the method described by Fehr et al. (1971).

Ten plants per plot of each cultivar were randomly sampled at the pod formation 
stage (R4) made for the dry matter and LAI. Plant sampled was separated into leaves, main stem and branches. Leaf area was determined by placing the leaf blades through a leaf area meter (LI-COR Li-3100, USA). Thereafter, dry matter was determined by dried in a forced-air dryer at $80^{\circ} \mathrm{C}$ for $72 \mathrm{hr}$. Ten plants per plot were randomly sampled from two interior rows of each plot at maturity and investigated for pod number, seed number, seed weight and sample seed yield.

\section{RESULTS AND DISCUSSION}

\section{Flowering and Maturing Dates}

The flowering dates in small seed soybean cultivars were on July 26 to August 7 and the maturing dates were on September 23 to October 9 (Table 1). K wangankong showed the latest flowering date on Aug 8 and Hannamkong showed the earliest flowering date on July 26. Hannamkong showed the fastest maturing date on September 23 and Insannamulkong showed the latest maturing date on October 9 . The days of from planting to flowering or to maturing were ranged as $39 \sim 52$ or $98 \sim 114$, respectively. Thus the difference of the flowering date between the earliest and latest cultivars was about 13 days and that of maturing date was about 16 days.

Table 1. Date of flowering (R1) and maturing (R8) stage, and the days from planting to R1 and R8 stage in late planted 22 small soybean cultivars.

\begin{tabular}{ccccc}
\hline \multirow{2}{*}{ Cultivars } & R1 stage & R8 stage & \multicolumn{2}{c}{ Days from planting date to } \\
\cline { 3 - 4 } (Mon. Day) & (Mon. Day) & R1 stage & R8 stage \\
\hline Hannamkong & 7.26 & 9.23 & 39 & 98 \\
Tawonkong & 7.29 & 9.24 & 42 & 99 \\
Sunamkong & 7.29 & 9.25 & 42 & 100 \\
Dachaekong & 8.03 & 9.25 & 47 & 100 \\
Namhaekong & 8.03 & 9.28 & 47 & 103 \\
Sobaegnamulkong & 8.02 & 9.29 & 46 & 104 \\
Sohokong & 8.02 & 10.03 & 46 & 108 \\
Paldokong & 8.01 & 10.03 & 45 & 108 \\
Saebyolkong & 8.02 & 10.01 & 46 & 106 \\
Dagikong & 8.05 & 10.01 & 49 & 106 \\
Anpyeongkong & 8.01 & 10.02 & 45 & 107 \\
Myeongjunamulkong & 8.02 & 10.02 & 46 & 106 \\
Eunhakong & 8.01 & 10.01 & 45 & 108 \\
Doremikong & 8.04 & 10.03 & 48 & 110 \\
Pungsannamulkong & 8.06 & 10.05 & 50 & 112 \\
Purwunkong & 8.01 & 10.07 & 45 & 112 \\
Kwangankong & 8.08 & 10.07 & 52 & 112 \\
Bukwangkong & 8.05 & 10.07 & 49 & 112 \\
Sorogkong & 8.07 & 10.07 & 51 & 113 \\
Somyeongkong & 8.06 & 10.08 & 50 & 113 \\
Sowonkong & 8.05 & 10.08 & 49 & 114 \\
Iksannamulkong & 8.07 & 10.09 & 51 & 106.9 \\
\hline Mean & - & - & 46.8 &
\end{tabular}




\section{Growth Traits}

Stem length at the pod formation (R4) stage ranged from 31 to $57 \mathrm{~cm}$ and the averages of stem length showed $43 \mathrm{~cm}$ in 22 small seed soybean cultivars. (Table 2).

Table 2. Growth characteristics of 22 small seed soybean cultivars at the pod formation stage (R4).

\begin{tabular}{|c|c|c|c|c|c|}
\hline Cultivars & $\begin{array}{l}\text { Stem length } \\
(\mathrm{cm})\end{array}$ & $\begin{array}{l}\text { Number of } \\
\text { node } \\
\left(\text { no. plant }{ }^{-1}\right)\end{array}$ & $\begin{array}{c}\text { Number of } \\
\text { branch } \\
\left(\text { no. plant }{ }^{-1}\right)\end{array}$ & LAI & $\begin{array}{c}\text { TDM. } \\
\text { (g plant }^{-1} \text { ) }\end{array}$ \\
\hline Hannamkong & $41 \pm 3.0$ & $15.0 \pm 1.8$ & $2.7 \pm 1.3$ & $3.8 \pm 0.3$ & $29 \pm 6.3$ \\
\hline Tawonkong & $33 \pm 2.8$ & $11.1 \pm 0.7$ & $2.8 \pm 1.2$ & $2.6 \pm 0.2$ & $27 \pm 6.9$ \\
\hline Sunamkong & $43 \pm 3.5$ & $12.6 \pm 0.9$ & $3.0 \pm 0.8$ & $3.3 \pm 0.6$ & $31 \pm 5.9$ \\
\hline Dachaekong & $32 \pm 3.7$ & $11.8 \pm 0.7$ & $3.0 \pm 1.1$ & $2.7 \pm 0.4$ & $28 \pm 5.1$ \\
\hline Namhaekong & $47 \pm 4.3$ & $11.9 \pm 0.8$ & $3.6 \pm 1.3$ & $3.0 \pm 0.2$ & $37 \pm 5.5$ \\
\hline Sobaegnamulkong & $31 \pm 3.1$ & $10.8 \pm 1.1$ & $3.0 \pm 0.9$ & $5.3 \pm 0.6$ & $40 \pm 4.6$ \\
\hline Sohokong & $43 \pm 4.1$ & $12.5 \pm 1.1$ & $3.9 \pm 1.5$ & $2.5 \pm 0.3$ & $33 \pm 5.1$ \\
\hline Paldokong & $49 \pm 3.2$ & $9.9 \pm 0.4$ & $3.0 \pm 1.0$ & $4.4 \pm 0.4$ & $46 \pm 7.1$ \\
\hline Saebyolkong & $49 \pm 2.8$ & $13.1 \pm 1.2$ & $3.4 \pm 0.5$ & $5.7 \pm 0.5$ & $42 \pm 6.9$ \\
\hline Dagikong & $38 \pm 1.9$ & $11.8 \pm 1.1$ & $3.5 \pm 1.1$ & $2.8 \pm 0.3$ & $32 \pm 6.9$ \\
\hline Anpyeongkong & $41 \pm 2.1$ & $11.5 \pm 0.3$ & $3.9 \pm 1.3$ & $2.5 \pm 0.3$ & $29 \pm 4.1$ \\
\hline Myeongjunamulkong & $33 \pm 1.5$ & $13.2 \pm 0.7$ & $3.8 \pm 0.8$ & $3.6 \pm 0.6$ & $47 \pm 5.0$ \\
\hline Eunhakong & $44 \pm 3.5$ & $11.9 \pm 1.1$ & $4.5 \pm 1.0$ & $6.1 \pm 0.4$ & $46 \pm 7.2$ \\
\hline Doremikong & $46 \pm 3.9$ & $12.6 \pm 0.8$ & $4.0 \pm 1.7$ & $3.2 \pm 0.2$ & $48 \pm 8.2$ \\
\hline Pungsannamulkong & $35 \pm 3.6$ & $12.2 \pm 1.1$ & $4.3 \pm 1.3$ & $3.6 \pm 0.4$ & $49 \pm 7.3$ \\
\hline Purwunkong & $57 \pm 2.8$ & $14.4 \pm 1.1$ & $3.0 \pm 0.6$ & $4.8 \pm 0.4$ & $41 \pm 5.0$ \\
\hline Kwangankong & $48 \pm 3.3$ & $12.7 \pm 0.9$ & $4.2 \pm 1.2$ & $4.2 \pm 0.3$ & $53 \pm 7.7$ \\
\hline Bukwangkong & $50 \pm 2.2$ & $13.2 \pm 1.0$ & $3.9 \pm 0.8$ & $3.7 \pm 0.5$ & $51 \pm 6.3$ \\
\hline Sorogkong & $52 \pm 3.8$ & $13.7 \pm 0.8$ & $4.0 \pm 1.1$ & $4.7 \pm 0.4$ & $54 \pm 6.1$ \\
\hline Somyeongkong & $37 \pm 2.0$ & $13.3 \pm 1.2$ & $3.8 \pm 1.4$ & $3.9 \pm 0.3$ & $41 \pm 6.1$ \\
\hline Sowonkong & $41 \pm 2.7$ & $13.4 \pm 1.2$ & $4.1 \pm 1.0$ & $3.4 \pm 0.2$ & $52 \pm 5.9$ \\
\hline Iksannamulkong & $49 \pm 2.8$ & $12.9 \pm 1.1$ & $3.8 \pm 1.5$ & $3.9 \pm 0.4$ & $52 \pm 9.5$ \\
\hline Mean & $43 \pm 7.0$ & $12.5 \pm 1.2$ & $3.6 \pm 0.6$ & $3.8 \pm 1.1$ & $41 \pm 9.0$ \\
\hline
\end{tabular}

LAI: leaf area index, TDM: total dry matter.

Sobaegnamulkong showed the smallest stem length of $31 \mathrm{~cm}$ and Pureunkong showed the longest stem length of $57 \mathrm{~cm}$. Among small seed soybean cultivars, the number of node and branch was ranged from 9.9 to 15.0 and from 2.7 to 4.5 and the averages of the number of node and branch were 12.5 and 3.6, respectively. In the case of leaf area index (LAI) at R4 stage, the average was 3.8, and Eunhakong, Sabyolkong and Sobaegnamulkong showed comparatively high LAI by $6.1,5.7$, and 5.3 , respectively. Tawonkong, Dachaekong, Sohokong, Dagikong and Anpyeongkong were relatively low by 2.6, 2.7, 2.5, 2.8, and 2.5 of LAI, respectively. The total dry matter (TDM) ranged from 27 to $54 \mathrm{~g}$ per plant, and Sorokong was the greatest value by $54 \mathrm{~g}$ at $\mathrm{R} 4$ stage and Tawonkong was the lowest by $27 \mathrm{~g}$. The average of TDM in 22 small seed soybean cultivars was $41 \mathrm{~g}$ per plant (Table 2). There was a highly significant difference $(\mathrm{r}=0.686)$ at $\mathrm{P}<0.01$ levels between TDM and LAI at R5 stage in 22 small soybean cultivars (Fig. 1). 


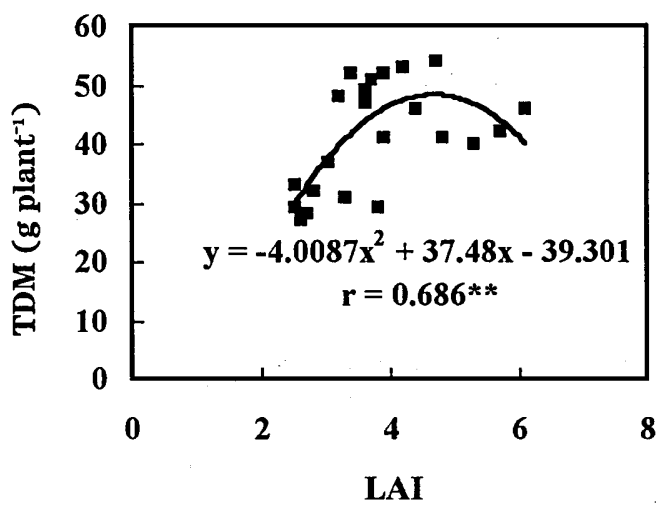

Fig. 1. Relationship between LAI and total dry matter (TDM) in 22 small seed soybean cultivars at seed development (R5) stage. **: significance at $\mathrm{p}<0.01$.

\section{Seed yield and Yield components}

The number of pods on total branch ranged from 15.6 to 46.6 per plant and the average number of pods was 27.0 (Table 3 ). The number of pods was collected each branch, $1^{\text {st }}, 2^{\text {nd }}, 3^{\text {rd }}$, and $4^{\text {th }}$ and above branch and counted. The number of pods on $2^{\text {nd }}$ branch showed the highest value by 7.6 , and followed by that of $3^{\text {rd }}, 1^{\text {st }}$ and over $4^{\text {th }}$ branch in this order. The number of pods on main stem ranged from 17.1 to 30.9 and the average number of pods on main stem in 22 soybean cultivars was 21.2. Therefore, the number of pods was more in branch than in main stem. However, Hannamkong, Tawonkong, Sobaegnamulkong and Paldokong showed lower pods in branch than in main stem. Also, the number of seeds in soybean cultivars was similar tendency as the number of pods (Table 3). The seed yield varied from 168 to $289 \mathrm{~g} \mathrm{~m}^{-2}$ and the average of 22 small seed soybean cultivars was $225 \mathrm{~g} \mathrm{~m}^{-2}$. The seed yield showed the greatest value in Sorokong of $289 \mathrm{~g} \mathrm{~m}^{-2}$ and the lowest value in Hannamkong of $168 \mathrm{~g} \mathrm{~m}^{-2}$.

\section{Relationship between seed yield and growth traits}

The relationship between the seed yield and the days from flowering to maturing date was high significant difference $(r=0.575, p<0.01)$ in 22 small seed soybean cultivars and there was a high significance difference $(\mathrm{r}=0.781, \mathrm{p}<0.01)$ between the seed yield and the days of planting to flowering date (Fig. 2). Previous studies conducted at optimal planting dates (mid-May) concluded that yield was more affected by altered source strength during the reproductive periods (R1-R7, stages according to Fehr et al., 1971) rather than by the vegetative period (emergence to R1) (Christy and Porter, 1982; Jiang and Egli, 1993). Also, Saitoh et al. (2003) reported that the seed yield was higher in the late maturing cultivars than in the early maturing cultivars at mid-June planting date. Parker et al. (1981) reported that the yield of early maturing soybean cultivars decreased more than that of the late maturing soybean cultivars planted after mid-June and the 
Table 3. Seed yield and yield components of branch and main stem in 22 small seed soybean cultivars.

\begin{tabular}{|c|c|c|c|c|c|c|c|c|c|c|c|c|c|c|}
\hline \multirow{3}{*}{ Cultivars } & \multicolumn{10}{|c|}{ Branch } & \multirow{2}{*}{\multicolumn{2}{|c|}{ Main stem }} & \multirow{3}{*}{$\begin{array}{c}100 \text { seed } \\
\text { w.t. (g) }\end{array}$} & \multirow{3}{*}{$\begin{array}{l}\text { Seed yield } \\
\quad\left(\mathrm{g} \mathrm{m}^{-2}\right)\end{array}$} \\
\hline & \multicolumn{2}{|c|}{$1^{\mathrm{st}}$} & \multicolumn{2}{|c|}{$2^{\text {nd }}$} & \multicolumn{2}{|c|}{$3^{\text {rd }}$} & \multicolumn{2}{|c|}{ Over $4^{\text {th }}$} & \multicolumn{2}{|c|}{ Total } & & & & \\
\hline & $\begin{array}{l}\text { Pod } \\
\text { No. }\end{array}$ & $\begin{array}{c}\text { Seed } \\
\text { No. }\end{array}$ & $\begin{array}{l}\text { Pod } \\
\text { No. }\end{array}$ & $\begin{array}{c}\text { Seed } \\
\text { No. }\end{array}$ & $\begin{array}{l}\text { Pod } \\
\text { No. }\end{array}$ & $\begin{array}{c}\text { Seed } \\
\text { No. }\end{array}$ & $\begin{array}{c}\text { Pod } \\
\text { No. }\end{array}$ & $\begin{array}{c}\text { Seed } \\
\text { No. }\end{array}$ & $\begin{array}{l}\text { Pod } \\
\text { No. }\end{array}$ & $\begin{array}{c}\text { Seed } \\
\text { No. }\end{array}$ & $\begin{array}{l}\text { Pod } \\
\text { No. }\end{array}$ & $\begin{array}{c}\text { Seed } \\
\text { No. }\end{array}$ & & \\
\hline Hannamkong & 5.2 & 10.7 & 4.8 & 8.8 & 3.5 & 5.6 & 2.1 & 4.1 & 15.6 & 29.2 & 23.8 & 51.1 & 8.9 & 168 \\
\hline Tawonkong & 6.3 & 12.1 & 8.4 & 16.3 & 6.3 & 13.8 & 2.0 & 4.4 & 23.0 & 46.6 & 28.4 & 53.4 & 7.7 & 189 \\
\hline Sunamkong & 5.8 & 12.4 & 8.1 & 17.3 & 6.9 & 13.0 & 4.0 & 7.3 & 24.8 & 50.0 & 24.3 & 48.1 & 9.6 & 190 \\
\hline Dachaekong & 5.6 & 12.5 & 7.2 & 16.3 & 6.0 & 13.7 & 3.4 & 7.9 & 22.2 & 50.4 & 19.0 & 42.9 & 7.2 & 169 \\
\hline Namhaekong & 5.0 & 9.2 & 7.4 & 14.6 & 6.9 & 13.9 & 5.0 & 9.9 & 24.2 & 47.7 & 23.5 & 37.2 & 14.4 & 269 \\
\hline Sobaegnamulkong & 5.5 & 10.5 & 6.5 & 13.7 & 4.0 & 7.7 & 2.8 & 5.9 & 18.7 & 37.7 & 22.0 & 42.1 & 9.2 & 222 \\
\hline Sohokong & 3.9 & 7.7 & 6.7 & 14.6 & 7.8 & 14.9 & 9.3 & 18.1 & 27.7 & 55.6 & 19.7 & 38.2 & 11.5 & 217 \\
\hline Paldokong & 6.7 & 13.3 & 7.5 & 15.6 & 5.1 & 10.8 & 1.4 & 2.9 & 20.6 & 42.6 & 26.2 & 50.8 & 12.8 & 242 \\
\hline Saebyolkong & 7.2 & 15.0 & 8.3 & 17.7 & 6.5 & 14.9 & 3.3 & 7.3 & 25.4 & 55.0 & 22.5 & 48.2 & 12.6 & 219 \\
\hline Dagikong & 5.2 & 11.7 & 4.7 & 12.2 & 4.7 & 10.4 & 5.2 & 14.6 & 19.8 & 48.9 & 19.3 & 45.6 & 12.0 & 226 \\
\hline Anpyeongkong & 3.6 & 7.3 & 4.9 & 11.4 & 5.7 & 13.5 & 4.2 & 10.4 & 18.4 & 42.6 & 17.1 & 40.5 & 10.7 & 204 \\
\hline Myeongjunamulkong & 7.9 & 12.6 & 7.8 & 13.0 & 9.5 & 15.2 & 11.5 & 21.8 & 36.7 & 62.7 & 21.5 & 49.6 & 11.3 & 219 \\
\hline Eunhakong & 7.6 & 15.7 & 7.2 & 18.9 & 8.4 & 20.5 & 6.2 & 14.0 & 29.4 & 69.1 & 18.2 & 42.9 & 10.4 & 215 \\
\hline Doremikong & 4.7 & 9.8 & 7.4 & 17.6 & 6.8 & 16.4 & 8.9 & 22.3 & 27.7 & 66.1 & 22.1 & 45.7 & 10.0 & 260 \\
\hline Pungsannamulkong & 7.8 & 16.4 & 10.2 & 22.1 & 8.2 & 16.9 & 11.2 & 23.9 & 37.3 & 79.2 & 28.7 & 66.5 & 9.1 & 241 \\
\hline Purwunkong & 5.4 & 12.9 & 8.1 & 18.6 & 10.0 & 12.4 & 2.9 & 6.3 & 26.4 & 50.1 & 15.3 & 27.7 & 14.0 & 263 \\
\hline Kwangankong & 6.4 & 13.0 & 7.1 & 16.3 & 7.0 & 12.9 & 8.5 & 15.0 & 29.0 & 57.3 & 17.5 & 37.5 & 12.2 & 275 \\
\hline Bukwangkong & 6.4 & 11.9 & 9.2 & 18.1 & 8.9 & 17.5 & 8.2 & 17.4 & 32.6 & 64.9 & 20.2 & 38.8 & 14.0 & 258 \\
\hline Sorogkong & 9.0 & 17.1 & 12.7 & 23.5 & 13.3 & 24.0 & 11.6 & 20.5 & 46.6 & 85.2 & 30.9 & 61.0 & 10.4 & 289 \\
\hline Somyeongkong & 9.9 & 22.7 & 12.5 & 28.3 & 11.4 & 22.2 & 6.2 & 14.1 & 40.0 & 87.3 & 29.5 & 67.8 & 7.4 & 278 \\
\hline Sowonkong & 8.5 & 19.2 & 12.9 & 30.7 & 9.5 & 22.4 & 10.0 & 37.4 & 41.0 & 109.8 & 18.3 & 43.2 & 9.6 & 267 \\
\hline Iksannamulkong & 6.3 & 12.4 & 9.2 & 19.1 & 9.2 & 18.1 & 8.8 & 18.3 & 33.6 & 68.0 & 20.6 & 41.4 & 11.5 & 282 \\
\hline Mean & 5.9 & 12.4 & 7.6 & 16.7 & 7.0 & 14.4 & 5.8 & 13.2 & 27.0 & 56.8 & 21.2 & 44.4 & 10.8 & 225 \\
\hline $\operatorname{LSD}(5 \%)$ & - & - & - & - & - & - & - & - & 5.9 & 11.3 & 8.1 & 14.5 & 1.0 & 24.5 \\
\hline
\end{tabular}




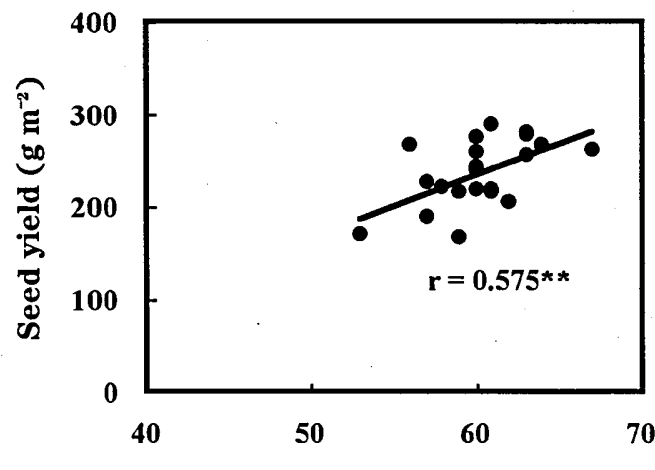

Flowering to maturing stage (Days)

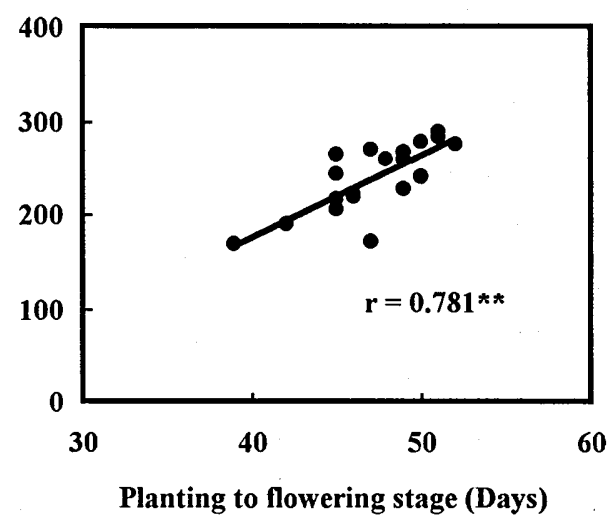

Fig. 2. Relationship between the seed yield and the days of flowering to maturing date or planting to flowering date in 22 small seed soybean cultivars. ${ }^{* *}$ : significance at $\mathrm{p}<0.01$.

maturity date of the early maturing cultivars was affected more by planting date than that of the late maturing cultivars. In this study, however, the seed yield had a higher correlation with the period of vegetative stage than the period of reproductive stage. Therefore, this result indicated that soybean planted at mid-June need to maintain the days of the vegetative period in order to ensure high productivity in small seed soybean cultivars.

On the other hand, there was a high significance $(\mathrm{r}=0.556, \mathrm{p}<0.01)$ between the seed yield and LAI at R5 stage in soybean cultivars (Fig. 3). A range of LAI for the optimal seed yield may be shown about 3.5 4.5 at R5 stage in small seed soybean cultivars. Board et al. (1996) reported that differences among cultivars significantly
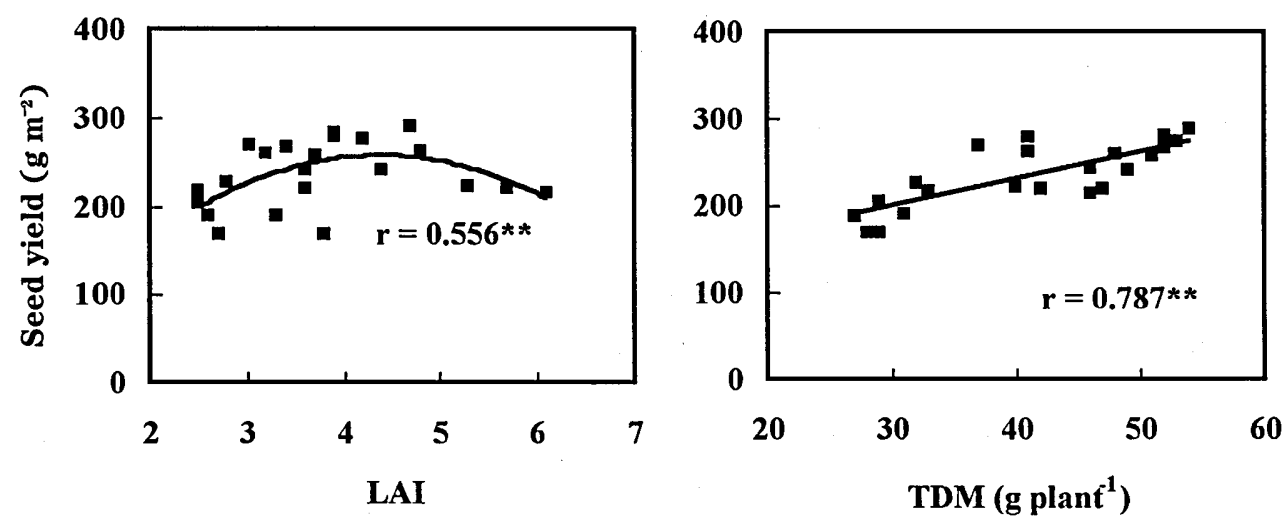

Fig. 3. Relationship the seed yield, and LAI or total dry matter (TDM) of small seed cultivars at R5 stages. ${ }^{* *}$ : significance at $\mathrm{p}<0.01$. 
affected TDM and LAI, and the seed yield was most highly correlated with TDM at R5 stage. The relation between the seed yield and TDM also showed high positive significance $(r=0.787, p<0.01)$. The statistical significance $(p<0.01)$ between the seed yield and the pod number by branch showed the $2^{\text {nd }}$ and $3^{\text {rd }}$ branches in 22 soybean cultivars (Fig. 4). Also, there was a significant relationship between the seed yield and the number of pods on $4^{\text {th }}$ and above branches but was no significant relationship between
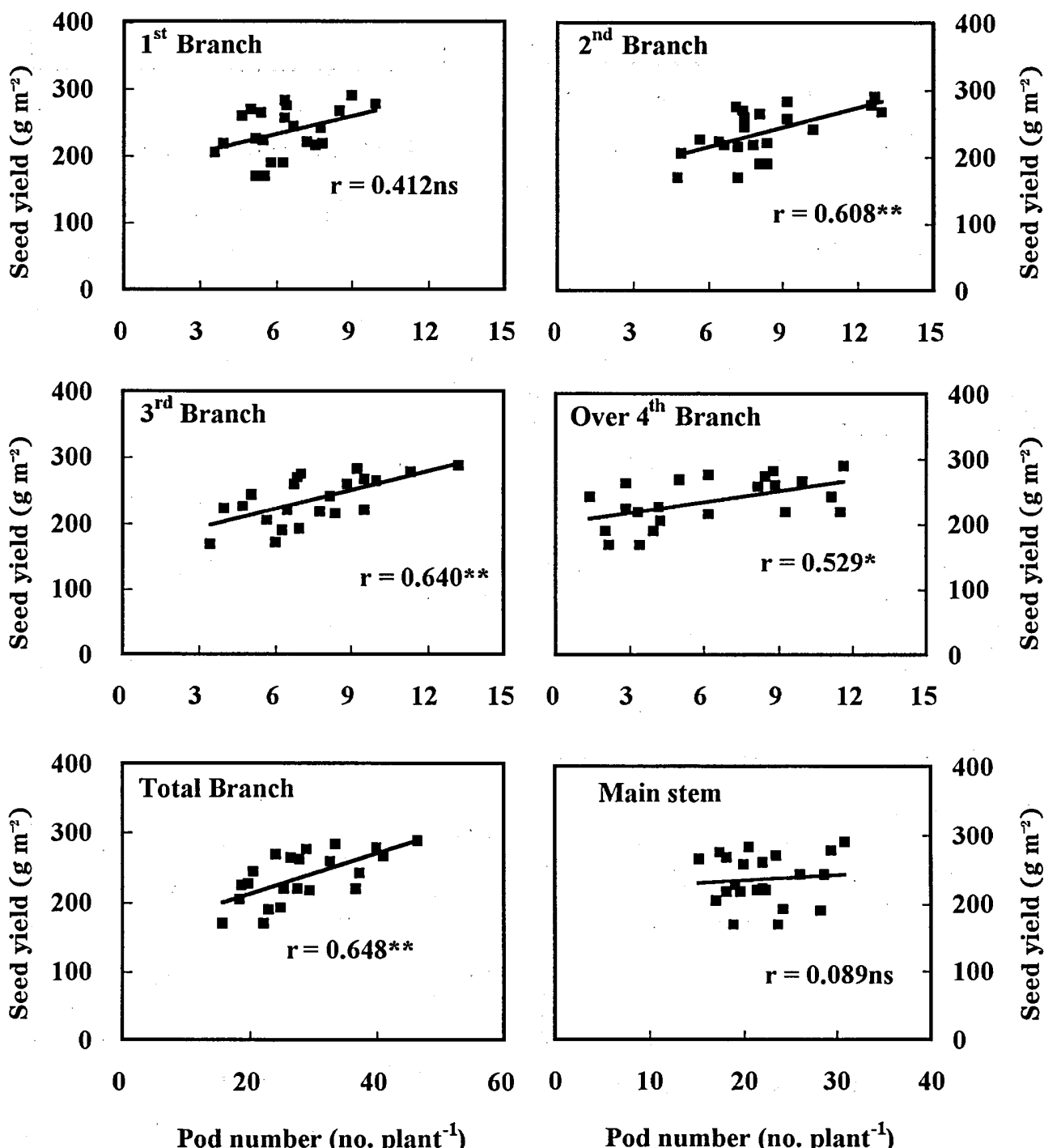

Fig. 4. Relationship between the yield and the pod number on main stem and branch in 22 small seed soybean cultivars. ${ }^{* *}$ : significance at $\mathrm{p}<0.01,{ }^{*}$ : significance at $\mathrm{p}<0.05$ and ns: no significance. 
the seed yield and the number of pods on $1^{\text {st }}$ branch. The correlation showed the highest significance by 0.640 in relation with $3^{\text {rd }}$ branch, and followed by $2^{\text {nd }}$, and $4^{\text {th }}$ and above branches in this order. Therefore, there was a high significant relationship $(r=0.648, p<$ 0.01 ) between the seed yield and the number of pods on total branches among 22 small seed soybean cultivars. Board (1985) reported that seed yield reductions of soybean at mid-June planting dates were more associated with reductions in branch rather than main stem seed yield. However, the relation between the seed yield and the number of pods on main stem showed no significant relationship $(\mathrm{r}=0.089, \mathrm{~ns})$. Results from this study indicated that in order to optimal seed yield of late planted (mid-June) small seed soybean cultivars, some cultivars could be breed which had more pods on the $2^{\text {nd }}$ and $3^{\text {rd }}$ branch.

\section{REFERENCES}

Board, J. E. 1985 Yield components associated with soybean yield reductions at nonoptimal planting dates. Agron. J., 77: 135-140

Board, J. E., W. Zhang and B. G. Harville 1996 Yield rankings for soybean cultivars grown in narrow and wide ropws with late planting dates. Agron. J., 88: 240-245

Christy, A. L. and C. A. Porter. 1982 Development, carbon mrtabolism and plant productivity. In "Photosynthesis", Vol. II, ed. by Govindjee, Academic Press, N.Y., pp. 499-511

Fehr, W. R., C. E. Caviness, D. T. Burmood and J. S. Pennington 1971 Stage of development descriptions for soybean, Glycine max (L.) Merrill. Crop Sci., 11: 929-931

Jiang, H. and D. B. Egli 1993 Shade induced changes in flower and pod number and flower and fruit abscission in soybean. Agron. J., 85: 221-225

Lee, Y. H. and K. Y. Park 2001 Research trends and future plan for varietal improvement of soybean in Korea. International symposium for development strategy for self-production of soybean (Glycine $\max$ L.). NHAES. RDA. Korea. pp. 56-78

Parker, M. R., W. H. Marchant and B. J. Mullinix, Jr. 1981 Date of planting and row spacing effects on four soybean cultivars. Agron. J., 73: 759-762

Paroda, R. S. 1999 Status of soybean research and development in India. Proc. World Soybean Research Conference VI. Compiled by Harold Kauffman Univ. of Illinois, Urbana-Champaign. pp. 372-379.

Pfeiffer, T. W. and D. Pilcher 1987 Effect of early and late flowering on agronomic traits of soybean at different planting dates. Crop Sci., 27: 108-112

Quattara, S. and D. B. Weaver 1994 Effect of growth habit on yield and agronomic characteristics of late-planted soybean. Crop Sci., 34: 870 - 873

Saitoh, K., T. Mahamood and T. Kuroda 2003 Difference in flower production and pod set performance among soybean cultivars with different stem-termination types and maturity groups. Jpn. J. Crop Sci., 72: 290-294

Weaver, D. B., R. L. Akridge and C. A. Thomas 1991 Growth habit, planting date, and row spacing effects on late-planted soybean. Crop Sci., 31: 805-810 